\title{
Effect of dietary CLA isomers on selenium, zinc, copper, chromium, magnesium and calcium levels in rat liver*
}

\author{
M. Czauderna ${ }^{1,4}$, J. Kowalczyk ${ }^{1}$, E. Bulska ${ }^{2}$, K. Boldižarova ${ }^{3}$, \\ K.M. Niedźwiedzka ${ }^{1}$, A. Ruszczyńska ${ }^{2}$ and L. Leng ${ }^{3}$ \\ ${ }^{1}$ The Kielanowski Institute of Animal Physiology and Nutrition, Polish Academy of Sciences \\ 05-110 Jabtonna, Poland \\ ${ }^{2}$ Faculty of Chemistry, Warsaw University \\ Pasteura 1, 02-093 Warsaw, Poland \\ ${ }^{3}$ Institute of Animal Physiology, Slovak Academy of Sciences \\ 04001 Košice, Slovak Republic
}

\section{ABSTRACT}

The effects of diets enriched with 1-2\% conjugated linoleic acid isomers (CLA) and/or $2 \mathrm{ppm}$ selenium $\left(\right.$ as $\mathrm{Na}_{2} \mathrm{SeO}_{4}$ ) on the level of $\mathrm{Se}, \mathrm{Zn}, \mathrm{Cu}, \mathrm{Cr}, \mathrm{Mg}$ and $\mathrm{Ca}$ in the rat liver were studied. Feeding selenium (Se) and/or CLA isomers resulted in significant changes or trends changing the level of $\mathrm{Zn}, \mathrm{Cu}, \mathrm{Cr}, \mathrm{Mg}$ and $\mathrm{Ca}$ in the liver. The dosage of Se, regardless of the presence of CLA isomers, significantly increased the Se level in the liver. Trans10cis12CLA in the diet most efficiently elevated $\mathrm{Zn}, \mathrm{Cu}, \mathrm{Mg}$ and $\mathrm{Ca}$ levels, and, numerically, the $\mathrm{Cr}$ content in the liver.

KEY WORDS: Se, $\mathrm{Zn}, \mathrm{Cu}, \mathrm{Cr}, \mathrm{Mg}, \mathrm{Ca}, \mathrm{CLA}$, interactions, liver, rat

\section{INTRODUCTION}

Numerous beneficial effects on health have been attributed to conjugated linoleic acid (CLA) isomer in view of the anticarcinogenic, antiatherosclerotic, antidiabetogenic and antiadipogenic properties ascribed to them (Belury, 2002; Lavillonniere et al., 2003). The predominant isomer in food is the cis9trans 11CLA (c9t11 CLA), followed by $t 7 c 9$ CLA, 11,13CLA (ct/tc), 8,10CLA (ct/tc) and t10c12 CLA isomer. On the other hand, selenium (Se), an essential trace element for mammals, has been found to be an integral part of the active site of cytosolic

\footnotetext{
* Supported by the State Committee for Scientific Research, Grant No. 3 PO6Z 03422 and by Project VEGA 2/3066/23

${ }^{4}$ Corresponding author: e-mail: m.czauderna@ifzz.pan.pl
} 
and mitochondrial glutathione peroxidases (cGPx), as well as phospholipid hydroperoxide glutathione peroxidase (PHGPx) (Czauderna et al., 2004). These enzymes reduce hydrogen peroxides, organic hydroperoxides, protecting tissues and polyunsaturated fatty acids (PUFA) in particular, from peroxidation damage. Moreover, it is well established that dietary selenate leads to increasing the CLA content in the rat liver. Therefore, the principal objective of this study was to examine the effect of feeding CLA on the level of $\mathrm{Se}, \mathrm{Zn}, \mathrm{Cu}, \mathrm{Cr}, \mathrm{Mg}$ and $\mathrm{Ca}$ in rat liver. The mechanism of the interaction between CLA and the assayed elements was considered. Rats were used as a model of monogastric animals.

\section{MATERIAL AND METHODS}

Ten groups of 7 female rats each (Wistar, Ifz: BOA), 8 weeks of age and an initial body mass $\sim 200 \mathrm{~g}$ were housed individually as described previously (Czauderna et al., 2004). Rats were fed Labofeed ad libitum or diets enriched in CLA isomers and/or 2 ppm Se $\left(\mathrm{as} \mathrm{Na}_{2} \mathrm{SeO}_{4}\right)$ (Table 1). After 28 days the rats were killed by $\mathrm{CO}_{2}$ and their livers removed, weighed and freeze-dried. The Se level in the livers was analysed by the fluorimetric method of Rodriguez et al. (1994), while $\mathrm{Zn}, \mathrm{Cu}, \mathrm{Cr}, \mathrm{Mg}$ and $\mathrm{Ca}$ contents by CPI-MS (Czauderna et al., 2004). The effects of CLA isomers or Se treatments were subjected to statistical analysis by the nonparametric Mann-Whitney $U$ test, while those of the combined Se and CLA treatments, by two-factorial analysis. The Statistica (version 6) and Excel 2000 programs were used.

\section{RESULTS AND DISCUSSION}

Feeding diets enriched in CLA isomers and/or Se resulted in changes of the assayed elements in the liver (Table 1). No lesion or symptoms of Se or CLA isomer intoxication were found. It was found that diets with only CLA isomers (Groups $3-6)$ resulted in significant $(\mathrm{P}<0.01$ or $<0.05)$ decrease in liver Se concentrations. In contrast, experimental diets enriched in Se, regardless of the presence of CLA isomers (Groups $2_{+\mathrm{se}}, 7_{+\mathrm{Se}}-10_{+\mathrm{Se}}$ ), significantly $(\mathrm{P}<0.01)$ stimulated accumulation of $\mathrm{Se}$ in the liver compared with control rats (Group 1) and the $\mathrm{Cr}$ level in the liver tended to increase. The presence of CLA isomers in the diets enriched in Se (Groups $7_{+\mathrm{Se}}-10_{+\mathrm{Se}}$ ) significantly decreased or tended to reduce the content of Se in the liver compared with the liver of rats fed the diet with only Se (Group $2_{+\mathrm{Se}}$ ). Moreover, administration of trans10cis12CLA significantly $(\mathrm{P}<0.01$ or $<0.05$ ) elevated the content of $\mathrm{Zn}, \mathrm{Cu}$, $\mathrm{Mg}$ and $\mathrm{Ca}$ in the liver, with an increasing trend in the $\mathrm{Cr}$ level. The results clearly demonstrate that feeding selenate, regardless of the presence of CLA isomers, only slightly promotes the accumulation of Se in the liver compared with dietary selenite. 
Table 1. Concentration of Se, $\mathrm{Zn}, \mathrm{Cu}, \mathrm{Cr}, \mathrm{Mg}$ and $\mathrm{Ca}$ in the liver ${ }^{1}$ of rats fed experimental diets ${ }^{2}$

\begin{tabular}{|c|c|c|c|c|c|c|c|c|}
\hline \multirow{2}{*}{ Group } & \multirow{2}{*}{ Additive } & \multirow{2}{*}{$\begin{array}{l}\text { Content of } \\
\text { additive in } \\
\text { the diet }\end{array}$} & \multicolumn{6}{|c|}{ Content of Se, $\mathrm{Zn}, \mathrm{Mg}$ and $\mathrm{Ca}$ in rat livers, $\mu \mathrm{g} / \mathrm{g}$ of $\mathrm{DM}^{3}$} \\
\hline & & & $\mathrm{Se}$ & $\mathrm{Zn}$ & $\mathrm{Cu}$ & $\mathrm{Cr}$ & $\mathrm{Mg}$ & $\mathrm{Ca}$ \\
\hline 1 & Control group & 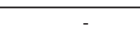 & $4.48^{\mathrm{ABCDEFGHa}}$ & $46^{\mathrm{A}}$ & $10^{\mathrm{A}}$ & 2.21 & $591^{\mathrm{a}}$ & $133^{\mathrm{a}}$ \\
\hline $2+\mathrm{Se}$ & $\mathrm{Se}$ & $2 \mathrm{ppm}$ & $5.77^{\mathrm{AbIJ}}$ & 35 & 9 & 2.52 & 515 & 102 \\
\hline 3 & CLA mixture & $1 \%$ & $4.17^{\mathrm{a}}$ & 45 & 11 & 4.78 & 641 & 115 \\
\hline 4 & Cis-9trans-11CLA & $1 \%$ & $3.91^{\mathrm{B}}$ & 48 & 12 & 5.58 & 662 & 122 \\
\hline 5 & trans-10cis-12 CLA & $1 \%$ & $4.07^{\mathrm{C}}$ & $72^{\mathrm{A}}$ & $16^{\mathrm{A}}$ & 4.60 & $904^{\mathrm{a}}$ & $183^{\mathrm{a}}$ \\
\hline 6 & CLA mixture & $2 \%$ & $3.89^{\mathrm{D}}$ & 52 & 12 & 4.85 & 697 & 137 \\
\hline $3_{+\mathrm{Se}}$ & $\begin{array}{l}\text { Se } \\
\text { CLA mixture }\end{array}$ & $\begin{array}{c}2 \mathrm{ppm} \\
1 \%\end{array}$ & $5.15^{\mathrm{EI}}$ & 48 & 11 & 3.08 & 664 & 148 \\
\hline $4_{+\mathrm{Se}}$ & $\begin{array}{l}\mathrm{Se} \\
\text { Cis-9trans-11 CLA }\end{array}$ & $\begin{array}{c}2 \mathrm{ppm} \\
1 \%\end{array}$ & $5.50^{\mathrm{F}}$ & 70 & 16 & 2.40 & 789 & 221 \\
\hline $5_{+\mathrm{Se}}$ & $\begin{array}{l}\mathrm{Se} \\
\text { trans-10cis-12CLA }\end{array}$ & $\begin{array}{c}2 \mathrm{ppm} \\
1 \%\end{array}$ & $5.23^{\mathrm{Gb}}$ & 34 & 8 & 3.29 & 464 & 78 \\
\hline $6_{+\mathrm{Se}}$ & $\begin{array}{l}\mathrm{Se} \\
\text { CLA mixture }\end{array}$ & $\begin{array}{c}2 \mathrm{ppm} \\
2 \%\end{array}$ & $5.12^{\mathrm{HJ}}$ & 35 & 8 & 3,81 & 470 & 116 \\
\hline
\end{tabular}

${ }^{1}$ for 4 weeks rats were fed diets enriched in the CLA and/or $\mathrm{Se}\left(\right.$ as $\left.\mathrm{Na}_{2} \mathrm{SeO}_{4}\right)$

${ }^{2}$ composition of the mixture of CLA isomers, \%: $t 11 t 13-2.9, t 10 t 12-.1, t 9 t 11-4.3, t 8 t 10-2.9$, $c 11 t 13-13.4, c 10 t 12-28.0, c 9 t 11$-28.6, $c 8 t 10-9.6, c 11 c 13-1.6, c 10 c 12-1.5, c 9 c 11-1.4, c 8 c 10$ 0.7. The composition of the cis-9trans-11 CLA and trans-10cis-12 CLA - 95 of $c 9 t 11$ and $t 10 c 12$ isomer, respectively (Czauderna et al., 2004)

${ }^{3}$ means in columns with the same letter are significantly different at ${ }^{\mathrm{A}, \mathrm{B}} \mathrm{P}<0.01$ or ${ }^{\mathrm{a}, \mathrm{b}} \mathrm{P}<0.05$

This finding may be explained by the different metabolic pathways of selenate and selenite. In contrast to selenite, which is immediately taken up by and reduced in red blood cells and then transferred to the liver, approximately $20 \%$ of selenate given to rats is excreted into the urine without any changes in its chemical form; the major portion of selenate is taken up by the liver, reduced and then utilized for the synthesis of selenoproteins or excreted by urine after being methylated (Shiobara et al., 1999). Recent results reinforce the finding that CLA isomers, especially trans10cis12CLA, promote oxidation in the liver. Trans 10 cis 12 CLA most efficiently enhanced oxygen consumption and energy expenditure in rats. In addition, cis9trans10CLA in cultured cancer cells also led to increased lipid peroxidation metabolites in examined cells, causing their apoptosis (Lavillonniere et al., 2003). So, CLA induced peroxidation by cellular antioxidant defense enzymes (e.g., cGPx, SOD or catalase). Indeed, conjugated trienoic fatty acids derived from the added CLA isomers (i.e. their metabolites) increased the formation hydroperoxides. Considering the above evidence and our presented work, we can suggest that CLA isomers (especially trans 10 cis 12 CLA), as an oxidative agent, stimulated biosynthesis of metallothionein (MT) (Czauderna and Rochalska, 1989; Moriarty-Craige and Jones, 2004), so the content of $\mathrm{Zn}, \mathrm{Cr}$ and $\mathrm{Cu}$ markedly increased in the liver. Indeed, the increase of the content of MT, possessing free sulphydryl groups, resulted in an increased accumulation yield of sulphur-philic 
metal ions (e.g., $\mathrm{Zn}, \mathrm{Cu}, \mathrm{Cr}, \mathrm{Hg}$ or $\mathrm{Ag}$ ) in the liver. MT, a cysteine-rich protein, played the principal role in reducing oxidative stress or liver toxins (such as heavy metal ions). On the other hand, it could be hypothesized that interactions between added selenate and CLA isomers (Groups $7{ }_{+\mathrm{Se}}-10_{+\mathrm{Se}}$ ), especially trans10cis 12CLA (Group $9_{+\mathrm{Se}}$ ), reduced the availability of added Se for formation of selenoproteins (like cGPx or PHGPx) due to the pro-oxidative activity of administered CLA isomers. Therefore, the Se concentration in the liver of rats fed diets enriched in Se and CLA isomers was lower (Groups $7_{+\mathrm{Se}}-10_{+\mathrm{Se}}$ ) compared with rats fed diets enriched only with selenate (Group $\left.2{ }_{+\mathrm{Se}}\right)$.

\section{CONCLUSIONS}

Adding selenate and/or CLA to the diet for 4 weeks resulted in small changes of the concentration of the assayed elements. Unexpectedly, the interaction between CLA isomers and selenate in the liver of monogastric animals may be considered antagonistic.

\section{REFERENCES}

Belury M.A., 2002. Dietary conjugated linoleic acids in health: Physiological effects and mechanisms of action. Annu. Rev. Nutr. 22, 505-531

Czauderna M., Kowalczyk J., Niedźwiedzka K.M., Wąsowska I., Pastuszewska B., Bulska E., Ruszczyńska A., 2004. Liver and body mass gain, content of CLA isomers and other fatty acids in the liver of rats fed CLA isomers and selenium. J. Anim. Feed. Sci. 13, 353-369

Czauderna M., Rochalska M., 1989. Use of INAA to study the interaction between Ag and Se, Zn, $\mathrm{Rb}, \mathrm{Fe}$ or Co in mice. J. Radioanal. Nucl. Chem. 129, 425-433

Lavillonniere F., Chajes V., Martin J., Sebedio J., Lhuillery, Bougnoux P., 2003. Dietary purified cis9trans 11 conjugated linoleic acid isomer has anticarcinogenic properties in chemically induced mammary tumors in rats. Nutr. Cancer 45, 190-194.

Moriarty-Craige S.E., Jones D.P., 2004. Extracellular thiols and thiol/disulfide redox in metabolism. Annu. Rev. Nutr. 24, 481-509

Rodriguez E.M., Sanz M.T., Romero C.D., 1994. Critical study of fluorometric determination of selenium in urine. Talanta 41, 2025-2031

Shiobara Y., Ogra Y., Suzuki K.T., 1999. Speciation of metabolites of selenate in rats by HPLC-ICPMS. Analyst 124, 1237-1241

\section{STRESZCZENIE}

Wpływ izomerów CLA w diecie na poziom selenu, cynku, miedzi, chromu, magnezu i wapnia w wątrobie szczurów

Badano wpływ diety zawierającej selenian sodowy (Se) i/lub izomery sprzężonego kwasu linolowego (CLA) na poziom $\mathrm{Se}, \mathrm{Zn}, \mathrm{Cu}, \mathrm{Cr}, \mathrm{Mg}$ i Ca w wątrobie szczurów. Dodatek Se i/lub CLA statystycznie stymulował gromadzenie się Se w wątrobie, dodatek trans10 cis12 CLA zwiększył stężenie $\mathrm{Zn}, \mathrm{Cu}, \mathrm{Mg}$ i Ca w wątrobie, natomiast liczbowo poziom $\mathrm{Cr}$. 